\title{
Reform and Innovation of Teaching Methods in Chinese University Education: A Questionnaire Survey of Inquiry Teaching Model Based on Microeconomics*
}

\author{
Lingyan Zheng ${ }^{1}$ \\ Ningbo University
}

\author{
Haohan Wang ${ }^{2}$ \\ Ningbo University
}

\author{
Fan $\mathrm{Lv}^{3}$ \\ Ningbo University
}

\begin{abstract}
This paper uses a questionnaire survey to conduct a detailed research of the teaching of microeconomics courses. According to the findings of the survey results, from the aspects of teaching content and teaching methods, combined with the characteristics of students, the practice of inquiry reform was carried out in the teaching of microeconomics. Through the teaching reform, students' final exam scores and satisfaction with teaching have been significantly improved, indicating that in the economics curriculum teaching, the adjustment of teaching content, introduction and inquiry teaching methods from the perspective of management has significantly promoted the improvement of teaching effectiveness.
\end{abstract}

Keywords

Inquiry Teaching Model • Microeconomics • Questionnaire Survey・ Innovation

\footnotetext{
* This work was supported by National Natural Science Foundation of China (Project number:71773057); Teaching and Research Project of Ningbo University (number: jyxmxzd1710; jyxmxyb201803) and Sponsored by K.C. Wong Magna Fund in Ningbo University. The author is very grateful to the editor and the anonymous referees for their insightful and constructive comments and suggestions, which have been very helpful in improving the paper.

${ }^{1}$ Business School, Ningbo University, Ningbo 315211, China. Email: zhenglingyan@nbu.edu.cn

${ }^{2}$ Correspondence to: Haohan Wang (PhD), Business School, Ningbo University, Ningbo 315211, China. Email:

wanghaohan@nbu.edu.cn

${ }^{3}$ Business School, Ningbo University, Ningbo 315211, China. Email: lvfan@ @bu.edu.cn

Citation: Zheng, L. Y., Wang, H. H., \& Lv, F., Reform and Innovation of Teaching Methods in Chinese University Education: A Questionnaire Survey of Inquiry Teaching Model Based on Microeconomics. Educational Sciences: Theory \& Practice, 18(5), 1197-1209. http://dx.doi.org/10.12738/estp.2018.5.020
} 
"Microeconomics" is a core course of business majors in China. As an external course, its own characteristics and the trend of economic globalization determine the importance of its use of English teaching, Therefore, it is far-reaching significance to adopt a full-English teaching method for courses with such international characteristics as microeconomics. Because microeconomics originated in the West, many British and American scholars have made great contributions in this field, and formed the research results written in English. The teaching in the original language is closer to the expression of the original author, and can maximize the connotation of related works. students learn knowledge in a full English environment (Tang, 2018). Through teaching in English, students learn to understand and think about problems in English, gain professional knowledge, and enable students to maximize their subjective initiative. Behind the original expression, you can understand and understand the Western people's thinking habits, ideological essence, cultural characteristics and strategic preferences, so that they can truly know themselves and cooperate with each other in international competition and cooperation, and have an "international strategic mind" (Gu, 2016). Its should be said that teaching in English is not only the teaching of microeconomics expertise, but also the expression and communication of English functional language.

In traditional teaching, overemphasizing the transfer of knowledge and the way students acquire knowledge and the enthusiasm and initiative of students' learning are neglected (Song, 2018). In the classroom, students lost their status as masters of learning and lost many opportunities to develop and improve their abilities. The so-called inquiry-based teaching means that Under the guidance of the teacher's inspiration, With the students' independent learning and cooperation discussion as the premise ,the existing materials as the basic research, Based on the world around the students and the reality of life, The teaching process provides students with the opportunity to fully express, question, explore, and discuss problems freely, allowing students to try their activities through individual, group, and group solutions, and apply their knowledge to solve practical problems. According to the four elements of inquiry-based teaching, namely, "problem guidance, multi-dimensional interaction, independent participation, scientific evaluation" The teaching of "Microeconomics" in English is intended to break through the traditional teaching and teaching methods, to provide targeted guidance based on the characteristics and practical goals of different organizational forms and cultivate comprehensive talents for comprehensive development.

Inquiry teaching can be traced back to the early 20th century. The first person to advocate and experiment in inquiry learning is Dewey. Dewey reckons that "education is not a matter of 'telling' and being told, It is an active and constructive process." Dewey (1997) and emphasizes child-centered and organizes teaching activities based on children's interests and attention. This teaching model with inquiry thinking has had a profound impact on American science education, and laid the foundation for inquiry learning. In the modernization movement of science education in the West in the late 1950s, American science educator Schwab believes that the original curriculum development, implementation, evaluation is very general, universal, too general, not targeted, personalized, lack of attention to specific educational scenarios. The root of the revitalization of the curriculum is shifting from the original theoretical pursuit to the practical model (Schwab \& Harper, 1969), In order to establish inquiry teaching as the cognition and methodology of science education. In-depth study of the process model and educational thoughts of inquiry teaching principles has laid a solid theoretical foundation for the development of inquiry teaching. That is, in the process of teaching, through the observation in the teaching 
situation, students discover problems, make assumptions, collect data, explain, obtain answers, and learn, communicate, test and explore the learning process. The most fundamental theoretical basis for inquiry teaching is constructivism, which was first proposed dates back to the Piagetin Switzerland (Piaget, 1964), He is one of the most influential psychologists in the field of cognitive development, and the school of children's cognitive development he founded is known as the Geneva School. Later, scholars have further enriched and perfected this theory. Such as Kohlberg's "moral development stage" theory, Sternberg's "intellectual ternary theory, successful intelligence theory", etc.

With the active promotion of inquiry teaching methods, many educational research institutions and schools in China have carried out experimental research on inquiry teaching and made great progress. However, the research of inquiry teaching is still in the exploration stage in China. Experts, scholars and front-line teachers have their own views. There are also some confusions and misunderstandings in theoretical discussion and practical application. There are also some problems in the inquiry teaching of the subject. For example, some scholars point out the theoretical basis of inquiry teaching from the philosophical point of view; many researchers also analyze the problems existing in inquiry teaching from the perspective of other disciplines.

In summary, compared with foreign research, the current research teaching in China is mostly based on philosophical research, historical research, and pedagogy, and less research is carried out by psychology research, sociology research, and technology research. Therefore, China's inquiry teaching research not only ushers in the opportunities brought about by the development of the times, but also faces many difficulties and difficult challenges in the research task itself. Educational theory workers, subject teaching experts and frontline teachers work together to strengthen the operational and empirical research of all aspects of inquiry teaching.

At the Ningbo University, the questionnaire survey of teaching situation Microeconomics courses in English, carried out a detailed investigation. According to the findings of the survey results, from the aspects of teaching content and teaching methods, combined with the characteristics of students, the practice of inquiry reform was carried out in the teaching of microeconomics. Through the teaching reform, the students' final exam scores and satisfaction with teaching have been significantly improved, indicating that in the microeconomics curriculum teaching, adjusting the teaching content from the perspective of management and introducing the inquiry-based teaching method has significantly promoted the improvement of teaching effectiveness.

\section{The status quo of microeconomics teaching based on questionnaires}

\section{Basic information of the investigation}

The survey targets eight junior college students in business administration, marketing, tourism management, logistics management, international economy and trade, information management and information systems, finance and economics. The sample of the survey is representative. both students have studied microeconomics course. The survey method is a questionnaire survey. The content of the questionnaire is divided into four parts: 
The first part is basic information statistics, including majors, genders etc. The second part is students' understanding and interest survey of microeconomics courses; the third part is students' cognition survey on the teaching objectives (or learning objectives) of microeconomics courses. The fourth part is the survey of the overall status of microeconomics teaching. A total of 300 questionnaires were distributed in this survey, and 292 were collected, of which 281 were valid questionnaires, and the effective recovery rate was $93.67 \%$.

\section{Statistics of survey results}

Student basic information. According to the 281 valid questionnaires recovered, 146 female students and 135 male students participated in the questionnaire survey, and the number of female students was slightly higher than that of male students. This is consistent with the current situation of economic management majors in Ningbo University. In addition, the proportion of male and female students surveyed by different professions varies, but it is similar to the ratio of male and female in the profession. Therefore, the sample of this questionnaire is representative.

Students' understanding and interest in microeconomics courses. As can be seen from Table 1, although only a few students have a preliminary understanding of the course before the microeconomics (the mean is significantly less than 2), and the majority of students do not understand the relationship between the course and the major (the mean is significantly less than 2), However, it does not affect students' understanding and interest in the importance of microeconomics courses. More than half of the students believe that it is necessary to have a course (the average is significantly greater than 2); the majority of students who have completed the course indicate that they are interested in the course (the mean is significantly greater than 2), and there are nearly a percentage Forty students have a strong interest in the course. The statistical results in Table 1 indicate that students are only perceptual about microeconomics courses. Therefore, in the teaching process, it is necessary for the instructor to help students to sort out the relationship between the microeconomics curriculum and other courses of their majors, the relationship between economics and business management, and the application of economic knowledge in the future work of students. Strengthening students' interest in learning in microeconomics courses, which will help improve teaching effectiveness.

Table 1

Student awareness and interest in survey courses on microeconomics

\begin{tabular}{|c|c|c|c|c|c|c|}
\hline \multirow[b]{2}{*}{ Project } & \multicolumn{3}{|c|}{ Level } & \multicolumn{3}{|c|}{ Single sample $\mathrm{T}$ test } \\
\hline & High & General & None, & $\begin{array}{l}\text { Mean } \\
\text { value }\end{array}$ & $\begin{array}{l}\text { Standard } \\
\text { deviation }\end{array}$ & T-value \\
\hline $\begin{array}{l}\text { The level of understanding of the } \\
\text { course before learning } \\
\text { microeconomics }\end{array}$ & $8 \%$ & $29 \%$ & $63 \%$ & 1.514 & 0.625 & $-14.312^{* * *}$ \\
\hline $\begin{array}{l}\text { The degree of necessity for setting up } \\
\text { a course in microeconomics }\end{array}$ & $64 \%$ & $21 \%$ & $15 \%$ & 2.523 & 0.723 & $10.223^{* * *}$ \\
\hline $\begin{array}{l}\text { The level of understanding of the } \\
\text { relationship between microeconomics } \\
\text { and the majors }\end{array}$ & $5 \%$ & $26 \%$ & $69 \%$ & 1.278 & 0.518 & $-15.276^{* * *}$ \\
\hline $\begin{array}{l}\text { After studying microeconomics, the } \\
\text { level of interest in the course }\end{array}$ & $39 \%$ & $44 \%$ & $17 \%$ & 2.32 & 0.727 & $5.627^{* * * *}$ \\
\hline
\end{tabular}


Table 2

Survey statistics of the teaching status of microeconomics

\begin{tabular}{lcccccccc}
\hline \multirow{2}{*}{ Project } & \multicolumn{4}{c}{ Satisfaction } & \multicolumn{3}{c}{ Single sample T test } \\
\cline { 2 - 9 } & Sery & Satisfied & General & Dissatisfied & $\begin{array}{c}\text { Very } \\
\text { dissatisfied }\end{array}$ & $\begin{array}{c}\text { Mean } \\
\text { value }\end{array}$ & $\begin{array}{c}\text { Standard } \\
\text { deviation }\end{array}$ & T-value \\
\hline $\begin{array}{l}\text { teaching } \\
\text { material }\end{array}$ & $14 \%$ & $10 \%$ & $23 \%$ & $42 \%$ & $11 \%$ & 2.727 & 1.212 & $\begin{array}{c}- \\
4.223^{* * *}\end{array}$ \\
\hline $\begin{array}{l}\text { teaching } \\
\text { content }\end{array}$ & $13 \%$ & $19 \%$ & $39 \%$ & $23 \%$ & $6 \%$ & 3.212 & 0.979 & $1.646^{*}$ \\
\hline $\begin{array}{l}\text { teaching } \\
\text { methods }\end{array}$ & $3 \%$ & $11 \%$ & $46 \%$ & $31 \%$ & $9 \%$ & 2.812 & 0.854 & $4.278^{* * *}$ \\
\hline $\begin{array}{l}\text { teaching } \\
\text { effect }\end{array}$ & $10 \%$ & $12 \%$ & $41 \%$ & $32 \%$ & $5 \%$ & 2.878 & 1.124 & -1.574 \\
\hline
\end{tabular}

Note: Each item in the table is assigned $1-5,1$ is very unsatisfactory, 5 is very satisfied; $\mathrm{t}$ value is the average test result of setting the statistical value to 3 (general); ***,** and * indicate significant at the $1 \%, 5 \%$, and $10 \%$ levels, respectively.

The current situation of microeconomics teaching. The statistical results of the survey on the current situation of micro-economics in English teaching are shown in Table 2. From Table 2, students participating in the survey, for the satisfaction of microeconomics courses learned generally not high, only the satisfaction of teaching content slightly above the general level and satisfaction with the textbooks and teaching methods used were significantly lower than the average level. More than half of the students are not satisfied with the textbook. The reason is that the microeconomics textbooks opened by Ningbo University are foreign textbooks. These textbooks have many page numbers and many contents. The good news is student satisfaction with teaching content exceeds the general level, one-third of students believe that satisfied or very satisfied. because in the past teaching process of microeconomics courses, the instructors have tried to adjust and arrange the appropriate teaching content.

\section{The practice of inquiry teaching reform in microeconomics course}

The results of the survey are worthy of our deep thought. Although it reflects that most students do not understand microeconomics at the beginning of their studies, they are interested in the course and agree with the need to open the course. Correspondingly, these students are not satisfied with the textbooks, teaching content and teaching methods selected in the current situation of microeconomics teaching. The main reason is that the current teaching is mainly based on teacher teaching, lack of cases, and it is difficult for students to convert abstract economic knowledge into concrete knowledge; At the same time, the teaching methods and means are relatively simple, It affects the initiative and enthusiasm of students' learning, which is not conducive to them to develop the habit of independent thinking and ultimately affects the effect of teaching. Therefore, it is necessary to reform the teaching of microeconomics courses.

Based on the reflection of the results of the questionnaire, the author applied for the teaching reform project of Ningbo University, combined with this teaching and research project and conducted comparative teaching reform experiments in two classes taught in the same semester. In order to test the effectiveness of the teaching reform, the two classes were divided into "experimental classes" and "control classes. "For the "experimental class", a variety of teaching methods such as case teaching and group learning were adopted, and the "contrast 
class" only adopted the case teaching method in the traditional teaching mode. The specific teaching reform practices are as follows:

\section{Defining the goal of teaching in English}

The coupling relationship between microeconomics and English makes the teaching in English an inevitable trend in the reform of microeconomics. However, the orientation of teaching objectives is the primary issue, if microeconomics truly implements all-English inquiry-based teaching and achieves good teaching results. The teaching objectives of the English-language teaching we have developed for microeconomics are as follows:

First, the goal of professional knowledge. The ultimate goal of all-English inquiry-based teaching is to better grasp the micro-economics professional knowledge. English is only used as a learning tool. It can't overemphasize the expression of English language and ignore the study of professional knowledge.

Second, English proficiency and skill goals. Use the teaching language to promote the development of English language ability, cultivate students' practical ability in English, express the content of the course in English and the ability to solve the content of the course.

Third, the he most important thing is to gradually cultivate the English thinking habits of economics majors. Later, we can further understand and master the international frontier theory and stimulate students' strong interest in scientific research.

\section{Accelerating the construction of teachers to promote English teaching}

The most urgent problem to be solved in the implementation of "microeconomics" in English teaching is the construction of a team of English teachers. Foreign teachers of relevant majors can be hired to teach and assign teachers of the school as teaching assistants. Foreign professional teachers are mainly responsible for helping teachers in the school to design teaching methods and innovative problems. The course is taught independently as the local teachers' business ability is improved.

Secondly, encourage relevant teachers to apply for the study abroad fund to go to foreign universities for course study and visits, daily intensive training of teachers in spoken English and encourage teachers to test, and continuously improve professional English and English communication skills, for teachers who conduct full English inquiry teaching. Conduct English communication to promote teachers to quickly improve their own quality.

In addition, teachers must be able to closely contact the reality and keep track of hot issues at home and abroad, so that they can be in-depth and vivid in the course of teaching, so that students can easily accept and understand (Guo, 2015). Also, the school will also set up a scholarship system to reward teachers who teach in English. In addition to the "quantity", it is necessary to allocate the time allowance according to the requirements of "quality", that is, to undertake the teaching of the whole English and obtain good teaching. The effect of the teacher to give rewards, improve teachers to undertake full English teaching work (Hou, 2017).

Through the training of local teachers, they not only have strong English ability, but also have a good understanding of the teaching content and economic operation mechanism of Western subjects, and can be 
based on their national conditions, familiar with the educational atmosphere of their own country. Finally, they have the advantage of "combing Chinese and Western".

This kind of faculty that can be freely converted in the "Chinese and Western platforms" is the key to the successful "English teaching" of economics.

\section{Flexible adoption of classroom teaching methods}

The implementation of "Microeconomics" in English teaching is limited by the language. Many students have a fearful attitude and their enthusiasm for learning is not high. Therefore, teachers should adopt more inquiry-based teaching methods in the classroom, including the following aspect:

Classroom teaching is closely integrated with student research. Due to the inquiry teaching method is very suitable for the teaching of modern economics, it can be widely used in the teaching of economics (Tang \& Guo, 2017), which leads students to think about the economic phenomena around them and trigger students to do Strong interest in research and participation in competitions. Teachers can be guided in the classroom to enhance students' ability to use economics knowledge to analyze problems and solve problems. At present, our teaching team has a number of teacher-directed SRIP project, Challenge-Cup projects and teachers to guide students to publish economics academic papers.

Research on background knowledge. Many students reflect that "Microeconomics" implements full English teaching is hard for them to learning. One of the important reasons is the lack of corresponding background knowledge. Therefore, the background knowledge is introduced in a step-by-step manner in the teaching process. At the end of each chapter, the teacher also needs summarize the content of each chapter and at the same time introduces the content to be introduced in the next chapter.

Teaching with multiple charts. "Microeconomics" is a discipline based on mathematical logic. There are many mathematical models, and charts should be used when introducing models. For example, the demandsupply model, the cobweb model, etc., the expression of the chart is more visual and intuitive, which can avoid complex theoretical explanations, bypass the language barriers, and then express them with mathematical formulas to be clear.

Use the case method to carry out "double master" teaching. In the teaching process, teachers mobilize the enthusiasm and creativity of students and stimulate students' motivation and train students' desire to participate in English teaching. The teaching of English in all should be based on the combination of the teaching design theory centered on "teaching" and "studying". Instead of instilling or transmitting knowledge to students, teachers create real problem situations, allowing students to construct new knowledge based on evidence through inquiry and interaction (Zhao, 2018). Interaction between teachers and students can increase students' interest in learning, so more case discussions should be conducted in the classroom. For example, when discussing the theory of information asymmetry, discuss the used car market and discuss the stock market in further; Discussing the issue of elderly insurance when teaching free rider theory, etc. By discussing the case, it not only helps students understand the basic principles of economics, but also cultivates students' English expression ability. At the same time, cultivate the correct management mind, work style, communication skills 
and collaborative spirit (Zheng, 2008). The improvement of student's learning interesting make classroom become a "teacher-led, student-centered" dual master model of inquiry teaching.

Introduce group cooperative learning. The main purpose and role of group cooperative learning is to let students actively and conscientiously think and cope with their own ideas and opinions in the process of cooperating to solve problems; Listen carefully to other people's opinions, get inspiration from others' speeches, and acquire more knowledge; Learn to question and refute, reflecting and understanding knowledge in the process of controversy. With reference to foreign teaching models, the group uses the case model to discuss teaching, and through the construction of a rich network course resource library, actively use the project cases of the enterprise teachers and micro-courses and other teaching methods to create interactive, self-study, evaluation, assessment and many other functions sharing. A professional and quality learning platform that mobilizes students' enthusiasm (Zhou \& Wang, 2018). Group study is suitable for groups of 4 to 6 people. The use of free team formation, so that students can communicate and collaborate smoother. At the beginning of the semester, according to the teaching objectives of the microeconomics course, a number of tasks are designed, and these tasks are assigned to the teams to find materials, discuss and summarize the reports and finally show in the classroom. Other groups of students participate in the discussion and give their score. In addition to the scoring between the groups, the author also evaluates the group from the perspective of the teacher, and conducts the selection of the best group, the best learning partner, the best spokesperson and the fastest progress award every month. The evaluation and incentives prompted a good situation of mutual help, mutual benefit and progress in the group. Practice shows that the group cooperative learning method makes up for the lack of teachers and students' participation in the traditional teaching process, fully mobilizes the initiative and enthusiasm of students, and enables them to consult, think and solve problems. Deeply understand the application of relevant micro-economic theory knowledge in economic management.

\section{Using the teaching support system}

Good teaching materials can lead to direct interest in learning. Reform and opening up have gradually brought us into line with the world economy and economics. Today we can directly select the latest international edition of textbooks and stand at the forefront of economic development. This has strong appeal to teachers and students. It is an important condition for teachers and students to cooperate in this course. During the research period, several of our teachers will discuss the selection of materials suitable for all-English inquiry teaching. Finally, the American economist Mankiw's "Principles of Economics" was selected as our teaching material. This economics textbook not only has frequent content updates, but also a wide variety of supporting teaching resources. The publishing house has set up a special website with many free resources, such as classroom presentations, problem banks, teacher manuals, teacher resource manuals, and teacher presentation manuals, study guides, video materials, reading materials, etc. There are also many websites in China, such as the Economics Education and Science Forum, which can download economic resources free of charge. There is course ware, lectures, and even video lectures on economics from foreign university teachers. In addition, the "Microeconomics" course is one of the ten core courses of the finance majors of the general higher education institutions identified by the Ministry of Education. Many well-known universities have built excellent courses 
for them, and there are a lot of wonderful teaching resources on the course website. Those resources are very helpful for our implementation of "microeconomics" in English-based inquiry teaching.

\section{Reasonable assessment of student achievement}

The innovation of evaluation methods, from a small perspective, is a change in the way of classroom teaching. From a big perspective, it is a change in teaching and even educational concepts.

We have clearly realized that using a single method for teaching and assessment is not suitable for today's diverse student needs. In order to adapt to a diverse society, students are required to receive a diversified education and hope to develop diverse skills and diversification knowledge. Through research, we intend to carry out inquiry-based reforms based on student-oriented evaluation methods, adopting multiple assessment forms and multiple communication channels.

The final score of the microeconomics course is the result of a comprehensive assessment, which includes the usual grades, mid-term quizzes and exam results. Usual grades include the usual classroom answering questions, group discussion in class, homework after class, etc. In the course of the course of Microeconomics, we plan to arrange two quizzes, so that we can evaluate them objectively and fairly. The learning effect of the students can also enable the teacher to keep abreast of the actual situation of the students and adjust the teaching steps in real time. For the final exam papers, our paper production plan highlights professionalism. In the end, the test students should still check the mastery of their professional knowledge and check the language ability. Therefore, when making test papers, we intend to minimize language barriers. It is best to increase the weight of objective questions such as choice, judgment, correction, etc. Exert questions, short answer questions, try to focus on calculation questions, etc., so that students do not affect the real results because of the language foundation.

\section{The effect of teaching reform practice in microeconomics}

\section{Analysis of differences in test scores}

There are 98 students in the two sophomore classes participating in the practice of teaching reform. Among them, there are 45 students in "Experimental class" and 53 students in "Control class". After the final exam, the test scores of the two classes of "Experimental class" and "Control class" were statistically analyzed. The results are shown in Table 3. The statistical results show that there are significant differences in the performance of the two classes. After the inquiry-based teaching reform, the results of the "Experimental class" with various teaching methods are significantly better than the "Contrast class" that only joined the case teaching method. The average scores of the two classes were 84.16 points and 79.54 points respectively and the standard deviation of the former was 8.842, which was less than the standard deviation of 11.991. It indicates that the distribution of the results of the "Experimental class" were more stable than that of the "Control class".

Table 3 shows the significant effect of the teaching reform. Of course, students' test scores are affected by various factors and it seems not very rigorous to simply attribute the significant difference between the two classes' scores to the teaching reform. Therefore, in order to further test the effect of the teaching reform, the 
questionnaire used before the teaching reform for the juniors was selected and the sophomore students of "Experimental class" and "Control class" were selected for the questionnaire survey.

Table 3

Statistics After the Reform of Teaching

\begin{tabular}{lcccccc}
\hline \multirow{2}{*}{ Project } & \multicolumn{4}{c}{ Descriptive statistics } & \multicolumn{2}{c}{ Mean comparisonT test } \\
\cline { 2 - 7 } & Average & Max. & Min. & Standard deviation & Mean difference & T-value \\
\hline Experimental class & 84.16 & 98 & 61 & 8.842 & 4.62 & $2.132 * *$ \\
Control class & 79.54 & 96 & 52 & 11.991 & 4.62 \\
\hline
\end{tabular}

Note. ${ }^{*} *$ means significant at the $5 \%$ significance level.

\section{Analysis of teaching satisfaction}

The sophomore of "Experimental class" and "Control class" were investigated and the results were obtained. The comparison between two control classes, the comparison between "Experimental class" and the junior students, and the comparison between the "Control class" and juniors were conducted respectively. The comparison results are shown in table 4 and 5 respectively.

Table 4

Statistics of Satisfaction After Teaching Reform

\begin{tabular}{|c|c|c|c|c|c|c|c|c|}
\hline \multirow{2}{*}{ Project } & & \multicolumn{5}{|c|}{ Satisfaction } & \multicolumn{2}{|c|}{$\begin{array}{c}\text { Meancomparison } \\
\mathrm{T} \text { test } \\
\end{array}$} \\
\hline & & $\begin{array}{c}\text { Very } \\
\text { satisfied }\end{array}$ & Satisfied & General & Dissatisfied & $\begin{array}{c}\text { Very } \\
\text { dissatisfied }\end{array}$ & $\begin{array}{l}\text { Mean } \\
\text { value }\end{array}$ & T-value \\
\hline teaching & Exp.C & $33 \%$ & $59 \%$ & $7 \%$ & $1 \%$ & 0 & 4.222 & \multirow{2}{*}{1.018} \\
\hline content & Con.C & $29 \%$ & $54 \%$ & $13 \%$ & $4 \%$ & 0 & 4.075 & \\
\hline teaching & Exp.C & $39 \%$ & $56 \%$ & $5 \%$ & 0 & 0 & 4.356 & \multirow{2}{*}{$3.095 * *$} \\
\hline methods & Con.C & $26 \%$ & $48 \%$ & $19 \%$ & $6 \%$ & $1 \%$ & 3.887 & \\
\hline teaching & Exp.C & $35 \%$ & $40 \%$ & $25 \%$ & 0 & 0 & 4.133 & \multirow{2}{*}{$1.932 * *$} \\
\hline effect & Con.C & $26 \%$ & $38 \%$ & $27 \%$ & $7 \%$ & $2 \%$ & 3.792 & \\
\hline
\end{tabular}

Note: each item in the table is assigned a score of 1-5, with 1 being very dissatisfied and 5 being very satisfied. $* * *, * *$ and $*$ are significant at the $1 \%, 5 \%$ and $10 \%$ levels respectively.

Table 5

Comparison of satisfaction before and after the teaching reform

\begin{tabular}{lllll}
\hline \multirow{2}{*}{ Project } & \multicolumn{2}{l}{ Experimental class VS educational reform } & \multicolumn{2}{l}{ Control class VS teaching reform } \\
\cline { 2 - 5 } & Mean difference & T-value & Mean difference & T-value \\
\hline Teaching content & 1.116 & $6.717 * * *$ & 0.969 & $6.242^{* * *}$ \\
Teaching methods & 1.562 & $11.639^{* * *}$ & 1.093 & $8.056^{* * *}$ \\
Teaching effect & 1.233 & $9.627^{* * *}$ & 0.892 & $6.004^{* * *}$ \\
\hline
\end{tabular}

Note: $* * *, * *$ and $*$ are significant at $1 \%, 5 \%$ and $10 \%$ levels respectively.

The results in table 4 show that as the two classes have the same arrangement of teaching contents, there is no significant difference in the evaluation of teaching contents between the "Experimental class" and the "Control class", while there is a significant difference in the satisfaction of teaching methods and teaching effects between the two classes. The students of the "Experimental class" were between "Satisfied" and "Very satisfied", while the students of the "Control class" were between "General" and "Satisfied". The reason is that there are many teaching methods for the "Experimental class", but only a single case teaching method for the "Control class". Therefore, student welcome diversity in teaching methods. As for the satisfaction of teaching effect, the "Experimental class" is also significantly higher than the "Control class", which indicates that the 
teaching reform in the "Experimental class" has achieved significant results, which is consistent with the results of the comparison in table 3 based on the final exam results.

Table 5 shows that the adjusted and changed teaching contents can better adapt to the needs of students as future information users. Therefore, the students of "Experimental class" and "Control class" are significantly more satisfied with the teaching contents than the students before the reform. In terms of teaching methods, although the "Control class " only introduced case teaching method, students' satisfaction was also significantly higher than before the reform, indicating that the introduction of case teaching method and group learning method in the teaching process of microeconomics courses was successful. As a result of the adjustment of teaching content and the improvement of teaching methods, the teaching effect after the reform was significantly improved compared with that before the reform, and the improvement of the "Experimental class" was much greater than that of the "Control class".

\section{Conclusions and recommendations}

According to the statistical analysis of the juniors before the reform, students are very interested in microeconomics courses at present, but they expect to make corresponding adjustments in teaching objectives and contents. At the same time, students also hope that teachers can adopt various teaching methods such as case teaching method when explaining abstract and professional theoretical knowledge, so as to mobilize students' initiative and enthusiasm in learning, enhance their interest in microeconomics courses and thus improve the teaching effect.

The questionnaire survey results of sophomore students after the reform indicated that the teaching contents of microeconomics courses were adjusted and various teaching methods such as case teaching method and group learning method were adopted to significantly improve students' test scores and satisfaction with the teaching effect. Therefore, the teaching reform from the aspects of teaching content and teaching methods has produced good results.

Microeconomics adopts full English way of inquiry teaching, which makes students learn and master the professional knowledge, and encourage the students to actively learn English, English through this bridge, access to international frontier theory, so as to improve students' scientific research ability, improve the comprehensive quality of students, and also is helpful to cultivating inter-disciplinary talent.

At present, with the acceleration of internationalization, there is a strong demand for international talents in the society. Therefore, majors and disciplines with international universality and comparability should be integrated with the international standards as soon as possible. The adoption of full English exploratory teaching can at least lead to the organization and teaching of the original textbooks selected from these professional disciplines that reflect the frontier of scientific development and enhance the timeliness. We should acknowledge the successful experience of foreign famous universities in subject construction, the high level achieved and the shortest distance from the development of science and technology. It is one of the effective 
ways to cultivate internationalized talents to select appropriate original textbooks and use English inquiry teaching method in the face of suitable students.

In addition, the reform and innovation of teaching can give full play to potential of teachers. The whole English teaching of microeconomics requires teachers to be proficient not only in economics, but also in English, with relatively strong English listening, speaking, reading and writing skills. From the selection of teaching materials, courseware making, teaching content, arrangement of exercises to the assessment of the basic use of English form, this series of links require teachers to have a large amount of reading and fluent spoken language, and if teachers cannot use English to teach and talk, it is difficult to achieve the requirements of barrier-free education. Therefore, it is hoped that the exploratory teaching reform can give full play to teachers' potential and build teachers' confidence. At the same time, studying abroad can greatly improve teachers' oral English, learn advanced foreign teaching concepts and exploratory teaching methods, and actively communicate with foreign scholars, so they will be more qualified for their jobs after returning to China.

For students, after graduation, business students are mostly engaged in jobs related to economy, trade and management in some multinational companies, joint ventures or foreign enterprises. The nature of the job makes it necessary for graduates to use English more than other majors. Mastering English helps them create more opportunities and excel in their work. Therefore, the full English teaching of basic business courses was carried out during the university according to students' needs. On the one hand, it increased students' professional knowledge and enhanced the "original flavor" of economics study. On the other hand, it will greatly increase students' English reading, so as to help students accumulate a large number of vocabularies, expressions, sentence patterns and so on, thus improving students' English application ability. Therefore, the full English teaching of basic courses of business can not only bear the heavy responsibility of subject goals, but also have the function of language improvement, so that business graduates can better adapt to social needs, which is conducive to students' further study abroad, foreign trade and economic exchanges, and improve the competitiveness of employment.

\section{References}

Dewey, J. (1997). Democracy and Education. The Free Press,1997-02.

$\mathrm{Gu}, \mathrm{R}$. (2016). The status quo of English teaching and the exploration of the "student-oriented" teaching method_- Taking the English course of financial management as an example. Journal of Jiangxi Radio and Television University, (01).77-82. http://dx.doi.org/10.13844/j.cnki.jxddxb.2016.01.017.

Guo, X. M. (2015). Discussion on the teaching of English courses in international economics and trade majors. Education Teaching Forum. (26), 125-127. http://dx.doi.org/CNKI:SUN:JYJU.0.2015-26-062.

Hou, F. Y. (2017). Exploring the English teaching of international business masters majors - taking the course of international settlement and trade finance as an example. Chinese Forestry Education, 35(5): 42-44. http://dx.doi.org/10.3969/j.issn.1001-7232.2017.05.010.

Piaget, J. (1964). Part 1 Cognitive Development in Children: Piaget Development and Learning. Research in Science Teaching, 2, 176-186. http://dx.doi.org/10.1002/tea.3660020306 
Schwab, J. J., \& Harper, W. R. (1969). The practical: A language for curriculum. School Review 78(1), 1-23. http://dx.doi.org/10.1086/442881

Song, Y. (2018). application of seminar teaching method in the course of macroeconomics. Chinese Modern Educational Equipment, (13), 30-33. http://dx.doi.org/10.13492/j.cnki.cmee.2018.13.011.

Tang, W. H. (2018). Interactive teaching in all-English course of western economics. China Light Industry Education, (1):86-90. http://dx.doi.org/10.3969/j.issn.1673-1352.2018.01.016.

Tang, X. H., \& Guo, H. X. (2017). Exploratory teaching and team learning with experiments_—A mode of economics teaching and thinking discipline construction and teaching Research. Higher Financial Education Research, 02 http://dx.doi.org/10.13782/j.cnki.2095-106x.2017.02.011.

Zhao, D. C. (2018). Promoting inquiry teaching in practice: To continue or not? Teaching Theory and Methods, 07 http://dx.doi.org/CNKI:SUN:KJJF.0.2018-07-007.

Zheng, L.Y. (2008). A Preliminary Study on the Application of Case Method in College Teaching--Taking Economics Teaching as an Example. Journal of Ningbo Institute of Education. (4): 32-35. http://dx.doi.org/10.3969/j.issn.1009-2560.2008.02.009

Zhou, D. N., \& Wang, X. C. (2018). Exploration of production and education integration-based accounting teaching in English. Journal of Dongguan University of Technology, 25(04), 114-117 http://dx.doi.org/10.16002/j.cnki.10090312.2018.04.021. 